\title{
Development of Cost Effective Nutritionally Balanced Food for Freshwater Ornamental Fish Black Molly (Poecilia latipinna)
}

Pai IK ${ }^{1 *}$, Maryem Shaikh Altaf ${ }^{1}$ and Mohanta KN ${ }^{2}$

${ }^{1}$ Department of Zoology, Goa University, Goa-403 206, India

${ }^{2}$ Fishery field Laboratory, ICAR Complex, Old Goa, Goa, India

\begin{abstract}
Fishery is one of the oldest professions of man and even today, it helps in food security and poverty alleviation, in many parts of the world. Fish culturing is major part of aquaculture. When natural fishery does not suffice the need of the society, world has gone for aquaculture to increase the productivity. On the same lines, in ornamental fishery too, man's interference in deciding the breed, formulating the feed, bringing changes in living conditions of the fishes, etc., is very much in vogue. To improve the health of the fishes, and their productivity of ornamental fisheries, nutrition plays a major role. In this direction, several attempts have been made by various workers, to alter the food and other environmental conditions. However, as there are hardly any attempt to develop low cost balanced food for ornamental fishes, present paper deals with formulating low cost nutritionally balanced food for Black Molly (Poecilia latipinna), a popular freshwater ornamental fishes has been attempted, by using locally available 'waste material' like Groundnut oil cake, Fish meal, Wheat bran, Snail, Marine Fish waste, Freshwater Fish waste, Chicken waste, Earthworms, Squids, Mussel, Chicken liver, Prawn meal, etc., The results obtained on growth and nutrition utilization indicated by weight gain and specific growth rate of Black Molly was highest, in fish fed with diet containing Snail meal, Prawn meal, Mussel meal and Chicken liver. The studies indicate that, these ornamental fishes can be reared well with animal based products, replacing agro based products, which can replace high cost commercial Fish meal.
\end{abstract}

Keywords: Ornamental fishery; Black molly; Fish meal

\section{Introduction}

The majority (>90\%) of freshwater ornamental fish are captive bred, compared to only about 25 of a total of 8000 , in the case of marine fish and the ornamental fish industry relies heavily on the export and import of introduced species [1]. In India too, like other countries, Guppy's, Swordtails, Platys and Molly's, due to their color, sturdiness, stability, ability to withstand considerable environmental variations, relatively easy maintenance etc., are most popular as aquarium fishes in ornamental fisheries.

Production of aquaculture species, in semi intensive pond culture system, demands the use of artificial feed, as supplementary source of nutrition. Using of such artificial diet for fishes can be traced as early as 1927 [2]. Most commonly used animal protein source in the diet is Fish meal, whose level could range between $10-50 \%$ of the operational costs [3]. Increasing cost and short supply of Fish meal has escalated the cost of Fish feed [4-6]. Thus, people have started concentrating on low cost Fish feed, by using plant protein sources [7]. Soybean products seem to be more promising, as a substitute, as they are almost half the price of Fish meal [8]. Though there is a tendency to use alternative plant and animal proteins, as a low cost substitute for Fish meal, such alternatives are known to have lower nutritional value, than Fish meal resulting in lower growth rates or a reduced performance of the cultured animals. In addition to the above, many of these protein sources containing substances that, might cause slight to severe effects on nutritional status of an animal. Insoluble fibers, Enzyme inhibitors, Saponins, Lectins, Tannis, Phytic acid and Gossypol are some of the important antinutrients, acting in the Gastro intestinal tract [9]. Despite the above, the search for alternative low cost substitutes is on throughout the world [10-13].

Ingested food nitrogen in fishes is either excreted as nitrogenous waste product or stored in growth products. The end product of protein catabolism in fishes is ammonia, which is generally considered as toxic, if allowed to accumulate. In many fishes, protein retention may be improved, by partly replacing dietary proteins by lipids. Such protein sparing effects have been demonstrated in Salmon [14,15], Trout [16], Carp [17], hybrid Striped Bass [18], Yellowtail [19], Red Sea Beam [20]. Improving digestibility of diet formulation and optimizing feeding regimens can improve feed utilization efficiency in farmed fishes [21]. It is also known that, fishes are able to regulate their daily food intake, based on their nutrient and energy requirements [22].

Fish meal is known for its high essential Amino acid a Fatty acids contents, high digestibility, low Carbohydrates, etc., Lipid is known to be one of the important nutrient next to protein, which plays a major role in optimum utilization of dietary Protein for growth. Lipids are almost completely digestible by fish and seem to be favored over Carbohydrates as an energy source [23]. Fishes are also known for utilizing protein preferentially over lipid or Carbohydrate as an energy source. Therefore, it is important from nutritional, environmental and economic point of view to improve protein utilization for tissue synthesis, rather than energy purposes.

In view of the above, locally available 'Waste material' like Groundnut oil cake, Fish meal, Wheat bran, Snail, marine Fish waste, freshwater Fish waste, Chicken waste, Earthworms, Squids, Mussel, Chicken liver, Prawn meal, etc., were analyzed to see their efficacy as alternative to Fish meal in one of the most popular aquarium fish species viz., Black Molly (Poecilia latipinna).

*Corresponding author: Pai IK, Department of Zoology, Goa University, Goa-403 206, India, Tel: +91-0832-6519281; E-mail: ikpai@unigoa.ac.in

Received November 04, 2015; Accepted November 18, 2015; Published February 15,2016

Citation: Pai IK, Altaf MS, Mohanta KN (2016) Development of Cost Effective Nutritionally Balanced Food for Freshwater Ornamental Fish Black Molly (Poecilia latipinna). J Aquac Res Development 7: 401. doi:10.4172/2155-9546.1000401

Copyright: (C) 2016 Pai IK, et al. This is an open-access article distributed under the terms of the Creative Commons Attribution License, which permits unrestricted use, distribution, and reproduction in any medium, provided the original author and source are credited. 


\section{Materials and Method}

One of the most popular Aquarium Fish viz., Black Molly (Poecilia latipinna) was utilized in the present experiments. Uniform sized, healthy fish fingerlings were procured from Freshwater ornamental Fish hatchery of ICAR research complex, Old Goa, India and were treated with $0.05 \%$ Potassium Permanganate solution, for two minutes, to make them free from external parasites and pathogens present if any. Before initiating the feeding trials, they were kept in 1.0 ton capacity cement tanks for conditioning/acclimatize to laboratory condition. During this period, they were fed twice daily, with practical diet other than experimental diet.

All the necessary fish feed ingredients such as Snail, Freshwater Fish waste, Marine Fish waste, Chicken waste, Earthworm, Squid, Mussel, Chicken liver, Prawns, Fish meal, Groundnut oil cake, Wheat bran, Vitamin and Minerals, Oil were obtained from local market. The ingredients were dried at $105^{\circ} \mathrm{C}$ to make them moisture free. Each ingredient was powdered separately using domestic grinder. The powdered material was then sieved through a mesh size of $0.5 \mathrm{~mm}$ dia. Later ingredients were analyzed, to determine their chemical composition (Table 1). Later, nine different feeds were formulated, based on the nutrient requirement (40\% protein and 6\% lipid, as determined earlier) (Table 2). The percent composition and proximate composition of the experimental diet is provided in Table 3. A weight of individual components of the diet was done, by using Sertorius Single Pan Balance

\begin{tabular}{|l|c|c|c|c|}
\hline Ingredient & Dry matter & Crude protein & Ether extract & Total ash \\
\hline Groundnut oil & 92.86 & 43.75 & 9.48 & 7.84 \\
\hline Fish meal & 93.12 & 56.00 & 8.80 & 14.12 \\
\hline Wheat bran & 92.54 & 10.94 & 2.24 & 7.68 \\
\hline Snail & 30.50 & 54.25 & 4.50 & 15.22 \\
\hline Marine fish waste & 33.56 & 56.87 & 9.60 & 14.24 \\
\hline Freshwater fish waste & 32.46 & 47.25 & 18.0 & 16.86 \\
\hline Chicken waste & 30.25 & 51.62 & 28.54 & 13.46 \\
\hline Earthworm & 17.16 & 50.75 & 15.00 & 12.66 \\
\hline Squids & 15.12 & 69.12 & 6.20 & 11.88 \\
\hline Mussels & 17.24 & 58.35 & 12.60 & 9.32 \\
\hline Chicken liver & 23.22 & 66.12 & 24.00 & 10.16 \\
\hline Prawn meal & 92.44 & 64.75 & 5.20 & 17.96 \\
\hline
\end{tabular}

Table 1: Composition (\% of dry matter) of food ingredient used for formulating diet for Black Molly (Poecilia latippina). and the mixture was prepared by thoroughly mixing the required components in a plastic tray. To these mixtures, required quantity of lukewarm, distilled water was added to prepare the dough, which was then put into hand palletizer and the $2 \mathrm{~mm}$ diameter pallets were drawn. These pallets were sun dried for 3-4 days, till they contain 7-8\% moisture level. Then, they were stored in air tight containers to be used later. Three each replicate of 10 fishes each, for each of the treatment, was placed in fish tank of $100 \mathrm{~L}$ capacity, in which $50 \mathrm{~L}$ of water of the quality as mentioned in Table 4 was used. All the batches were fed twice daily, with the experimental diet. The body weight gain after a month of treatment has been mentioned in Table 5. The data obtained was subjected for statistical analyses like ANOVA and the comparison among the groups, was done by Duncan multiple range test at $\mathrm{P}>0.05$.

\section{Results}

Table 1 provides the data on Composition (\% of dry matter) of the food ingredients used for formulating diet for Molly. It can be seen that among the ingredients Fish meal has highest dry matter $(93.12 \%)$ in comparison with lowest dry matter (15.12\%) in Squids. Crude protein was observed to be highest in chicken liver $(66.12 \%)$ in comparison with $10.94 \%$ of crude protein in wheat bran. Further, maximum and minimum of ether extract was recorded in Chicken waste $(28.54 \%)$ and Wheat bran (2.24\%) respectively. Analyses for total Ash, showed that the maximum ash was in Prawn meal (17.96\%), compared to a minimum of $7.68 \%$ of ash in wheat bran.

Table 2 Exhibits the ingredients composition (\% of dry matter) of the diet fed to Molly fishes. In all the experimental feeds fish meal and Vitamin and minerals was kept constant (10\% and 5.0\% respectively) while other ingredients were fed to the experimental batched in varied concentrations.

Proximate composition (\% dry matter) of the experimental diet, which provides data on dry matters, crude protein, ether extract and ash, has been provided in Table 3. It can be seen that, dry matter ranged from 92.4 (in Snail) to $94.2 \%$ (in Squid meal and Prawn meal). Crude protein was maximum in Marine Fish waste meal (41.90\%) and was minimum in Mussel meal (39.96\%) though, the difference was statistically insignificant. Ether extract showed maximum in Chicken liver (13.07\%) and a minimum of $7.23 \%$ in Snail meal. Similarly, Ash content was highest in Prawn meal (13.54\%) in comparison with lowest Ash contents in Chicken waste (9.68\%).

\begin{tabular}{|c|c|c|c|c|c|c|c|c|c|}
\hline \multirow[t]{2}{*}{ Ingredient } & \multicolumn{9}{|c|}{ Experimental diet } \\
\hline & $\begin{array}{l}\text { T-1 (Snail } \\
\text { Meal) }\end{array}$ & $\begin{array}{c}\text { T-2 } \\
\text { (Freshwater fish } \\
\text { waste) }\end{array}$ & $\begin{array}{c}\text { T-3 } \\
\text { Marine fish } \\
\text { waste) }\end{array}$ & $\begin{array}{c}\mathrm{T}-4 \\
\text { (Chicken } \\
\text { waste) }\end{array}$ & $\begin{array}{c}\mathrm{T}-5 \\
\text { (Earthworm) }\end{array}$ & $\begin{array}{c}\text { T-6 } \\
\text { (Squid) }\end{array}$ & $\begin{array}{c}\text { T-7 } \\
\text { Mussel) }\end{array}$ & $\begin{array}{c}\text { T-8 } \\
\text { (Chicken liver) }\end{array}$ & $\begin{array}{c}\text { T-9 } \\
\text { (Prawn meal) }\end{array}$ \\
\hline Snail meal & 45.0 & --- & --- & --- & --- & --- & -- & --- & --- \\
\hline $\begin{array}{l}\text { Freshwater fish } \\
\text { waste }\end{array}$ & --- & 48.0 & --- & --- & --- & -- & -- & --- & -- \\
\hline Marine fish waste & --- & --- & 42.0 & --- & --- & --- & --- & --- & --- \\
\hline Chicken waste & -- & --- & --- & 46.0 & --- & --- & -- & --- & -- \\
\hline Earthworm & --- & -- & -- & --- & 54.0 & -- & -- & --- & -- \\
\hline Squid & --- & --- & --- & --- & --- & 36.0 & --- & --- & --- \\
\hline Mussel & --- & --- & --- & --- & --- & -- & 38.0 & --- & -- \\
\hline Chicken liver & --- & --- & --- & --- & ---- & --- & --- & 40.0 & -- \\
\hline Prawn meal & --- & --- & --- & --- & --- & --- & --- & --- & 38.0 \\
\hline Fish meal & 10.0 & 10.0 & 10.0 & 10.0 & 10.0 & 10.0 & 10.0 & 10.0 & 10.0 \\
\hline Groundnut cake & 20.0 & 25.0 & 25.0 & 25.0 & 25.0 & 22.0 & 28.0 & 22.0 & 20.0 \\
\hline Wheat bran & 18.0 & 12.0 & 14.0 & 15.0 & 15.0 & 25.0 & 29.0 & 23.0 & 25.0 \\
\hline Vit. and Min. & 5.0 & 5.0 & 5.0 & 5.0 & 5.0 & 5.0 & 5.0 & 5.0 & 5.0 \\
\hline Oil & 2.0 & --- & --- & --- & -- & 2.0 & -- & --- & 2.0 \\
\hline
\end{tabular}

Table 2: Ingredient composition (\% of dry matter) of the diet fed to Black Molly (Poecilia latippina) Fingerlings. 
Physico-chemical parameters of the water, in which experimental animals were maintained is provided in Table 4 . The data reveals that, the water used for maintain the Fishes was very much normal and values obtained were acceptable for conducting such experiments.

\section{Discussion}

In aquaculture, diet cost accounts to over $50 \%$ of the operating cost, in intensive aquaculture, depending upon many factors, such as protein level, source, type of ingredient, and manufacturer's practices etc., the animal byproducts (ABM) meal, such as the one like Snails, Freshwater Fish waste, Marine Fish waste, Squid, Poultry industry waste can be used as substitute. Added advantage is that, these do not cause any deleterious effects on the fishes. Such attempts have been made earlier too [24], who used Earthworms, Poultry Egg Shell dust, Plant Rhizome, Wheat flour etc., as a substitute, for commercial Fish meal. The study revealed better that growth, length, gonad development, fertility in the Fishes fed with specially prepared feed, followed by dried Earthworm diet. Chong and Hashim observed higher man body length, in red sword tail Xiphophorus helleri, when they were fed several times. They reported that, more energy food is required, before spawning, for gonadal development and production of eggs. While, James and

\begin{tabular}{|l|c|c|c|c|}
\hline Treatment/diet & \multicolumn{4}{|c|}{ Parameters } \\
\hline & Dry matter & Crude protein & Ether extract & Ash \\
\hline T-1 (Snail) & 92.4 & 40.73 & 7.23 & 12.72 \\
\hline $\begin{array}{l}\text { T-2 (Freshwater } \\
\text { fish waste) }\end{array}$ & 92.6 & 40.53 & 12.16 & 12.88 \\
\hline $\begin{array}{l}\text { T-3 (Marine fish } \\
\text { waste) }\end{array}$ & 93.2 & 41.90 & 7.68 & 13.96 \\
\hline $\begin{array}{l}\text { T-4 (Chicken } \\
\text { waste) }\end{array}$ & 93.6 & 41.72 & 17.08 & 9.68 \\
\hline T-5 (Earthworm) & 92.8 & 40.86 & 10.34 & 12.36 \\
\hline T-6 (Squid) & 94.2 & 40.06 & 7.75 & 11.76 \\
\hline T-7 (Mussel) & 93.4 & 39.96 & 8.03 & 11.42 \\
\hline T-8 (Chicken liver) & 92.8 & 40.65 & 13.07 & 10.96 \\
\hline T-9 (Prawn meal) & 94.2 & 40.28 & 7.32 & 13.54 \\
\hline
\end{tabular}

Table 3: Proximate composition (\% dry matter) of the experimental diet.

\begin{tabular}{|l|c|}
\hline Parameter & Range \\
\hline Temperature (Deg. C) & $26.7-28.4$ \\
\hline $\mathrm{pH}$ & $7.2-7.7$ \\
\hline Dissolved oxygen(mg/lit) & $6.55-7.23$ \\
\hline Hardness $\left(\mathrm{CaCo}_{3} / \mathrm{Lit}\right)$ & $88.0 .-103.0$ \\
\hline Alkalinity $\left(\mathrm{CaCo}_{3} / \mathrm{Lit}\right)$ & $97.0-107.0$ \\
\hline Nitrate $(\mathrm{mg} / \mathrm{Lit})$ & $12-20.0$ \\
\hline Nitrite $(\mathrm{mg} / \mathrm{Lit})$ & $0.06-0.09$ \\
\hline
\end{tabular}

Table 4: Water parameters measured for the experiment on formulation of practical diet for Black Molly (Poecilia latipinna).
Sampath [25] found that, females of $X$. helleri with frequent meals exhibited higher gonad weight, and Gonado-somatic index. In 1964, Hester reported that, scarcity of food will result in reduced fertility, in Guppy Fishes. He further reported that, female Fish needs adequate Protein, Fat, Vitamins and Minerals for egg development and spawning, as yolk is composed of Phospholipo proteins, an amalgam of Minerals (Phosphorus), a Protein and Lipid. It is also known that, Protein is also required for forming follicle in Embryo.

In the present studies, the replacement of high cost fish meal, with the animal by product meal (ABM) and agro-based products, are used to formulate practical diet, for Black Molly, to observe the growth and dietary performance. The study indicate that, the growth was better, in the fish fed with diet containing Squid meal, Prawn meal, Chicken liver and Mussel meal. Thus, it can be concluded that, such substitution could be used to replace the costly commercial Fish meal [26,27].

\section{References}

1. FAO (2015) World review of fisheries and aquaculture, FAO, United Nations

2. Ida Mellen (1927) The Natural and Artificial Foods of Fishes. Transactions of the American Fisheries Society Volume 57: 120-142.

3. Akiyama DM, Dominy WG, Lawrence AL (1991) Penaeid shrimp nutrition. In Marine Shrimp culture: Principles and Practices, Elsevier Publ. Amsterdam The Netherlands.

4. HiGuera M, Gardenete G (1989) Fuentes alternativas de protean y energia en acuicultura. Alimentacion en Acquaculture FEUGA, Madrid.

5. McCoy HD (1990) Fishmeal-the critical ingredient in aquaculture feeds Aquaculture magazine 16: 43-50.

6. Bimbo AP, Crowtber B (1992) Fish meal and oil: Current uses. Jl of Am Chem Soc 69: 221-227.

7. Tacon AGJ, Jaskson AJ (1985) Utilization of conventional and unconventional protein sources in practical fish feeds. Nutrition and Feeding in fish, Academic Press, London.

8. Dabrowski K, Poczynski P, Kock G, Berger B (1989) Effects of partially or totally replacing fish meal protein on growth, food utilization and proteolytic enzyme activities in rainbow trout (Salmo gairdneri): new in vivo test for exocrine secretion. Aquaculture 77: 29-49.

9. Krogdahl A (1986) Anti-nutrients effecting digestive functions and performance in poultry. Proc. Of the $7^{\text {th }}$ European poultry conf., World Poultry Sci. Association, Paris.

10. Tacon AGJ (1993) Fish ingredient for carnivorous fish species: alternatives to fishmeal and other fishery resources, FAO, Fish Circ.

11. Stafford EA, Tacon AGJ (1985) The nutritional evaluation of dried earthworm meal (Eisenia foetida Savigny, 1826) included at low levels of production diets for rainbow trout, Salmo Gairdneri Richardson. Aquaculture and Fisheries Management 16: 213-222.

12. Pongmaneerat I, Watanabe $T$ (1991) Nutritive value of protein of feed ingredient for carp. Cyprinus carpio, Nippon Suisan Gakkaishi 57: 503-510.

13. Rumsey GL (1993) Fish meal and alternate source of protein in fish feeds update. Fisheries 18: 14-19.

\begin{tabular}{|c|c|c|c|c|c|c|}
\hline \multirow[t]{2}{*}{ Diet } & \multicolumn{6}{|c|}{ Nutritional indices } \\
\hline & Initial weight (g) & Final weight (g) & Weight gain (g) & FCR & Specific Growth Rate & PER \\
\hline Snail meal & $0.83 \pm 0.02^{\mathrm{a}}$ & $1.71 \pm 0.06^{c}$ & $0.88 \pm 0.04^{\mathrm{d}}$ & $1.93 \pm 0.03^{a}$ & $2.39 \pm 0.04^{c}$ & $1.28 \pm 0.01^{\mathrm{c}}$ \\
\hline Freshwater fish waste & $0.88 \pm 0.02^{\mathrm{a}}$ & $1.97 \pm 0.07^{\mathrm{b}}$ & $1.09 \pm 0.05^{b}$ & $1.76 \pm 0.02^{c}$ & $2.67 \pm 0.06^{b}$ & $1.40 \pm 0.02^{\mathrm{b}}$ \\
\hline Marine fish waste & $0.95 \pm 0.03^{\mathrm{a}}$ & $1.89 \pm 0.02^{\mathrm{bc}}$ & $0.94 \pm 0.02^{\mathrm{cd}}$ & $1.84 \pm 0.03^{b}$ & $2.30 \pm 0.08^{c}$ & $1.30 \pm 0.01^{c}$ \\
\hline Chicken waste & $0.92 \pm 0.03^{a}$ & $2.07 \pm 0.06^{b}$ & $1.15 \pm 0.05^{a}$ & $1.70 \pm 0.02^{c}$ & $2.690 .09^{b}$ & $1.41 \pm 0.01^{\mathrm{b}}$ \\
\hline Earthworm meal & $0.95 \pm 0.03^{a}$ & $1.99 \pm 0.04^{b}$ & $1.05 \pm 0.01^{\mathrm{bc}}$ & $1.75 \pm 0.01^{c}$ & $2.48 \pm 0.04^{c}$ & $1.41 \pm 0.03^{b}$ \\
\hline Squid meal & $0.91 \pm 0.02^{\mathrm{a}}$ & $2.53 \pm 0.09^{a}$ & $1.62 \pm 0.05^{\mathrm{a}}$ & $1.47 \pm 0.02^{\mathrm{d}}$ & $3.42 \pm 0.07^{a}$ & $1.69 \pm 0.03^{a}$ \\
\hline Mussel meal & $0.90 \pm 0.02^{\mathrm{a}}$ & $2.45 \pm 0.09^{a}$ & $1.55 \pm 0.05^{a}$ & $1.51 \pm 0.02^{d}$ & $3.35 \pm 0.07^{a}$ & $1.66 \pm 0.04^{a}$ \\
\hline Chicken liver & $0.86 \pm 0.02^{\mathrm{a}}$ & $2.37 \pm 0.06^{a}$ & $1.51 \pm 0.06^{\mathrm{a}}$ & $1.53 \pm 0.04^{d}$ & $3.37 \pm 0.08^{a}$ & $1.62 \pm 0.04^{a}$ \\
\hline Prawn meal & $0.88 \pm 0.02^{\mathrm{a}}$ & $2.46 \pm 0.08^{a}$ & $1.58 \pm 0.06^{\mathrm{a}}$ & $1.49 \pm 0.02^{\mathrm{a}}$ & $3.42 \pm 0.04^{\mathrm{a}}$ & $1.67 \pm 0.02^{\mathrm{a}}$ \\
\hline
\end{tabular}

Table 5: Growth and dietary performance of Black Molly (Poecilia latipinna) fed with different diets. 
Citation: Pai IK, Altaf MS, Mohanta KN (2016) Development of Cost Effective Nutritionally Balanced Food for Freshwater Ornamental Fish Black Molly (Poecilia latipinna). J Aquac Res Development 7: 401. doi:10.4172/2155-9546.1000401

14. Garcia M, Zamora S, Lopez MA (1981) The influence of partial replacement of protein by fat in the diet on the protein utilization by the rainbow trout (Oncorhynchus mykiss). Comp Biochem Physiol 68B: 457-460.

15. Johnson F, Hillested M, Austreng E (1991) High energy diets for Atlantic salmon. Effects on pollution, Fish nutrition in practice. Biarritz (France) Les Colloques 61: 391-401

16. Beamish FWH, Mediandn TE (1986) Protein sparing effects in large rainbow trout, Oncorhynhus mykiss Aquaculture 55: 35-42.

17. Watanabe T (1987) Lipid nutrition in fish. Comp Biochem Physiol 73: 3-15.

18. Nematipour GR, Brown ML, Gatlin DM (1992) Effects of dietary energy: protein ratio on growth characteristics and body composition of hybrid striped bass Morone chrysops x M. saxtilis. Aquaculture, 107: 359-368.

19. Shimeno S, Hosokawa H, Takeda M (1979) The importance of carbohydrates in the diet of carnivores fish. Proc World Symp Finfish Nutr Fishfeed Technol 1: $20-23$

20. Takeuschi T, Shiina Y, Watanabe T (1991) Suitable protein and lipid levels in diet for fingerlings of red sea bream Pagrus major. Nipp Suis Gakk 57: 521-527.
21. Cho CY, Bureau DP (2001) A review of diet formation strategies and feeding systems to reduce excretory and feed waste in aquaculture. Aquacul Res 32 : 349-360.

22. Kaushik SJ, Madela F (1994) Energy requirements, utilization and supply to salmonids. Aquaculture 124: 81-97.

23. Cowey CB, Sargent JR (1977) Lipid nutrition in fish. Comp Physiol 57B: 269-273.

24. Chakrabarty I, Gani Md.A, Misra A, Chaki KK, Sur R (1995) Digestive enzymes in 11 freshwater teleost fishes in relation to food habit and niche segregation. Comparative Biochemistry and physiology 112: 167-177.

25. James R, Sampath K (2004) Effect of animal and plant protein diets on growth and reproductive performances in an ornamental fish Xiphophorus helleri. Ind J Fish. 54: 75-86.

26. Hexter FJ (1964) Effects of food supply on the fecundity in the guppy, Lebistes reticulates (Peters). J Fish Res Board Can 21: 757-764.

27. Tacon AGJ, Stafford EA, Edwards CA (1983) A preliminary investigation on the nutritive value of three terrestrial lumbricid worms for rainbow trout. Aquaculture 35: $187-199$ 